\title{
Discussions for developing an Academic Organization for motivating the Corporate People's Higher Education
}

\author{
Arulanantha Samy Santhiyagu \\ Department of Automobile Engineering, Hindustan Institute of Technology and Science, Padur Campus, \\ Chennai-603103.
}

\begin{abstract}
Education makes all the people highly efficient in their skills and talents. Educational institutions offer various degree programs for the students to promote and honor their knowledge potential. Even most of the academic institutions nowadays are trying to provide practical knowledge to the peoples those who are studying their higher level courses in their campus. It is because of the importance of the practical knowledge requirements to the all learners. So industry people those who are having much more practical knowledge should be assessed by the institution at any cost. Those people are the backbone of industry; continuously they are applying their skills to improve the knowledge through hard work. They are striving hard to keep the industry's economic rate under control. Also, this paper contains some data related to the establishment of such organizations, levels of management required, and benefits to the corporate people.
\end{abstract}

Keywords:- Social status; higher education policies; assessment methods; university standards in India; industry based learning; industry human resource \& developments; motivations; academic institutions

\section{Introduction}

Teaching-learning process takes a vital role in all academic institutions. The quality checking on these teaching and learning sides of the academic institutions is difficult to measure till today. The various contents delivery methods in teaching and assessment methods in student's evaluation have been changing drastically in all academic institutions in the past few decades. Whatever the improvements have been identified in all matured institutions, a livelihood of the institutions always depends upon the work done by the students and teaching staff. There are two cases mainly involving with this research topic; 1 . Teacher - student relationship in academics, 2.Teacher - student relationship in an industry. Teachers are trying hard to produce more good students; for measuring that they are following various assessment methods among the students. The goal of every teacher may not be achieved as many years goes on due to the students poor performances. But, most of the students, after leaving the college or school, would produce much efficient work in their working environments. But, in the industry, even peoples have more knowledge about what they are doing and more attention in their work, they do not have any certification in relevance with their academic record or any other certification issued by universities unless they are having any links to academic institutions. Valuation is needed in the first case, but in the second case it should be evaluated, as just what corporate peoples are doing in an industry? The first case occurs in academic institutions; obliviously the second case occurs in an industry. Experience level in doing research is more in an Industrial scenario. Time management in industries will be given in a very affordable format.

Quratul-Ain Manzoor, (2012) this study focuses the following central factors, empowerment and employee recognition for making a good employee motivation which improves the strength of the organization. An effective Organization ensures that employee motivation satisfies them or not, if it is not, it should find some other ways to fulfil their needs at any cost. This statement leads to talk about their academic certification for their knowledge contribution and skills development. Fengliang Li*, Mengying Zhou and Baolong Fan (2014) this paper pointed out that few opportunities only available for the students those who are studying higher education in distance mode. David Boud* and Nancy Falchikov (2006) in this paper, it is observed that there are two assumptions made upon the purposes of the assessment plan. One is for certification, another one is for validating their performances. Whatever it may be, assessment includes the motivation process, and this motivation depth may not be measured accurately in academic institutions. But, it should be measurable in industries because the worth of the people's work or contribution is the biggest outcome expected in industries. The motivation will be improved so that they can do well their duties. If their work was encouraged by the academic peoples by offering certification, there may be a chance to increase their publications as well.

Rafikul Islam Ahmad ZakiHj. Ismail, (2008) The following factors were discussed in this paper: 1. A Full appreciation of work done, 2. Interesting work, 3. Feeling of being in on things, 4. Good working conditions, 5. Good wages, 6. Sympathetic help with personal problems, 7. Personal or company loyalty to employees, 8. 
Promotion and growth in the organization, 9. Job security. The first point insists that full appreciation is needed most, if it is taken by any academician (representing universities, Research and Development companies, engineering colleges etc.) to enrich their fulfilments, obviously, it focuses towards certification. It also focuses that any management development program should be incorporating the factors that affect the working lives of the workers.

MUOGBO U.S. (2013) In this paper, a sentence "The researcher, therefore suggest that more research should be conducted on the relationship and influence of rewards on worker's performance using many private and public organizations which will be a handy tool that could be used to provide solutions to individual conflict that has resulted from poor reward system" shows that many private and public organizations could be used to motivate them effectively.

\section{What can be reviewed: "A new method to motivate corporate peoples through academic institutions?"}

It has been identified in so many academic institutions that there is no bridge between academic curriculum structure and industry applications. Syllabus is framed fully with some books without focusing the outcome of individual student's interest and attainment of course outcome. It is quite different from student's expectation and industry needs. These have been changing through by implementing OBE (Outcome Based Education) and CBCS (Choice Based Credit System) systems in academic institutions. The assessment is based on exam oriented in academic institutions, whereas, in an industry, the governing rule is fully based on "moneyman-machine" rule. It may be observed that there is no such knowledge measure or assessment process based on only knowledge potentials taken by high-level management in industries, also, this reduces the number doctor profiles in industries, even the domain knowledge might be more than the general expectations on student's performance from central, private Universities for Higher studies.

Daniel Tan Lei Shek, Lu Yu, Florence Ka Yu Wu \& Wen Yu Chai (2015) in this paper, it is identified that hands-on workshops made student's learning to interest and enjoyable. This paper also includes other learning techniques such as group projects, visualized method such as short video sharing; it may be adopted in Tomorrow's Leaders subjects and some Freshman Seminars. All these kinds of activities are available in an industrial environment so that their contribution towards work will be enriched. The certification process may be simplified by applying simple assessment techniques upon their work and performance.

The literature and various studies concluded the following factor: empowerment and recognition have a positive effect on employee motivation. More the empowerment and recognition of employees in an organization is increased, more their motivation to work will be enhanced. Anyway, motivation is taken as one of the main input that includes all relationship required between an employee and organization. The research focused education is mostly appreciated in all academic institutions. Even exam oriented cannot be relaxed, these relaxation limits are up to the level in which the state of research output will be giving more benefit than exam oriented approach. Students are out of focused while they are studying books without any point of interest in it. An Industry needs high qualified and enriched academic system when corporate peoples are offered by the degree in student centric approach. With professional development such as promotion and increment, if corporate people would have been provided with a degree, which should be equivalent to the degree which is provided by academic professional universities, it definitely increases their satisfaction. University takes peoples who come out from it updating their knowledge in their domain so they need to get reward must. The human values are assessed based on only their knowledge exposed in a particular domain. It should not be assessed by only academic professionals. For this, an academic professional would be interested in the assessing process for them. Academic professionals can follow the student-centric approach while taking assessments.

The following table provides the attribute relationships between academician and industrial persons and the output measure with its impacts. Part time courses may increase the stress to the people, sometimes it may not, but it doesn't offer any domain knowledge particularly in their subject field in which they are working for, because the curriculum is already designed. The designed curriculum may have some subject contents, but not much focused to particular field. If consider a part time course B.E, it is availed for students those who are working in company for the past few years after finishing their diploma degree in particular discipline, these eligibility conditions does not bother about in which subject they are working for.

\begin{tabular}{|l|c|c|l|}
\hline \multicolumn{1}{|c|}{ Attributes } & Academician & Industrialist & ObservationsorSubjecttodiscuss \\
\hline Duty & $\begin{array}{l}\text { Teach to their } \\
\text { students }\end{array}$ & Task completion & Nil \\
\hline Guide & Can do & Cannot do & $\begin{array}{l}\text { No problem to Industrialist. } \\
\text { Already everybody is in } \\
\text { professional status. }\end{array}$ \\
\hline
\end{tabular}




\begin{tabular}{|l|l|l|l|}
\hline $\begin{array}{l}\text { Knowledge } \\
\text { Assessment }\end{array}$ & $\begin{array}{c}\text { Can do. It gives } \\
\text { awards to students. }\end{array}$ & Cannot do & $\begin{array}{l}\text { Who can assess them? } \\
\text { Industry HR can do. But that } \\
\text { assessment doesn't include } \\
\text { offering degrees based on their } \\
\text { knowledge gained. }\end{array}$ \\
\hline $\begin{array}{l}\text { Knowledge } \\
\text { measure } \\
\begin{array}{l}\text { availing } \\
\text { through various } \\
\text { degree } \\
\text { programmes }\end{array}\end{array}$ & $\begin{array}{l}\text { Possibilities to } \\
\text { learn more or join } \\
\text { in higher studies. }\end{array}$ & $\begin{array}{l}\text { Cannot do in } \\
\text { their home } \\
\text { plant. They need } \\
\text { to go academic } \\
\text { institutions. }\end{array}$ & $\begin{array}{l}\text { Who can offer this facility in } \\
\text { their home environment? } \\
\text { Possibly only by corporate } \\
\text { universities. }\end{array}$ \\
\hline
\end{tabular}

Table.1. Comparative Studies of various attributes between academician and industrialists

If the diploma student is working in a foundry\& forging company, this domain knowledge can be considered to offer degree with some academic assessment methods such as online exam, assignments, books to refer based on their own interest and presentations.

\section{Proposal for an Organization for Promoting Industrial People}

In part-time courses, repeatedly they are learning the theory knowledge, because, in academic institutions, that is the one and only thing can be provided by the institutions. No need part-time classes for industry people if their knowledge will be assessed based on their work and related domain knowledge. CBCS for industry people's choice and conversion of the academic syllabus to industry syllabus should be reviewed through this organization.

\section{Hierarchy of Management}

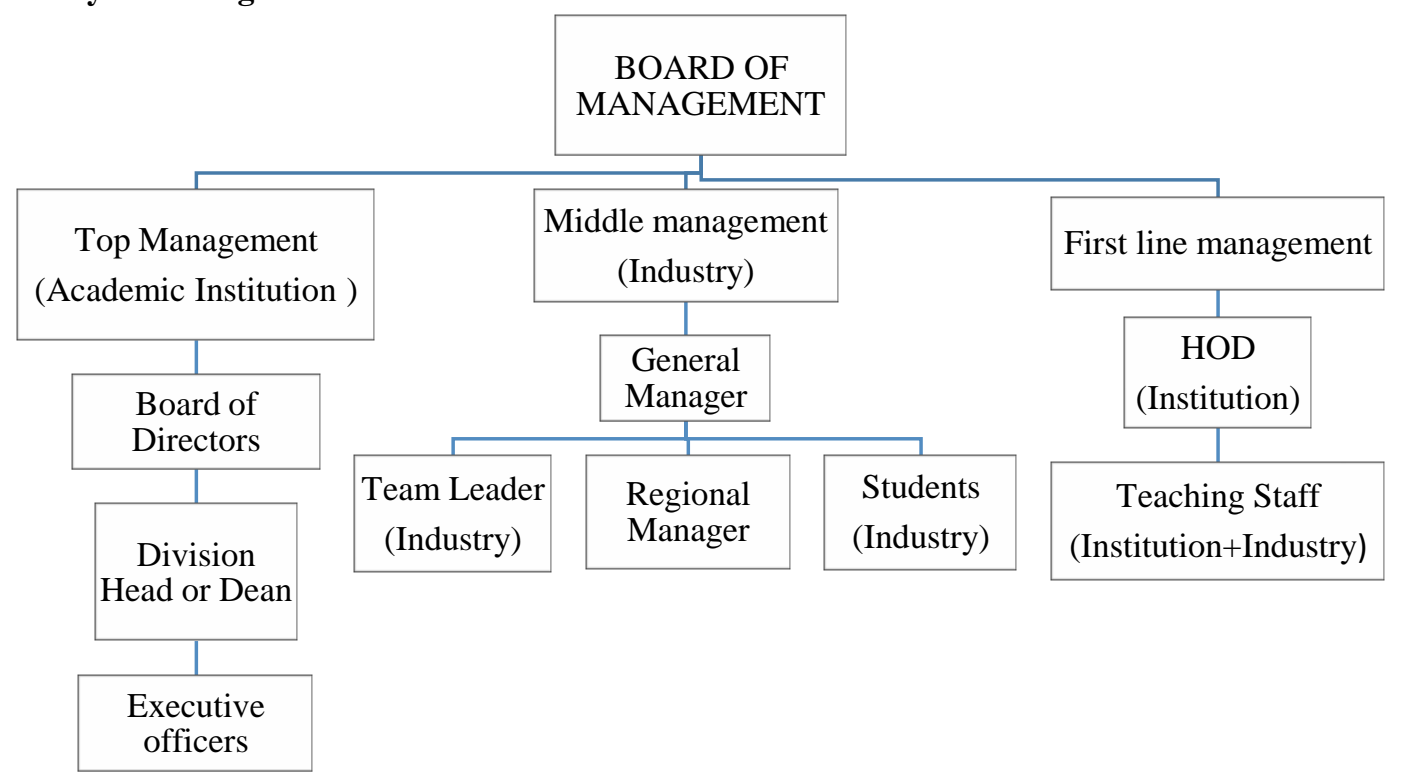

Fig. 1. Levels of Maagement

It is proposed to have maximum three levels of management to control the functions of the proposed institution. The sub-divisions are shown in fig.2, top level management includes the following functions, such as student's admission and its related issues, Examination results, curriculum design, recruitment of teaching staff and security related issues. Middle-level management includes functions such as the conduct of examination, discipline control, participation in students' curricular activities and supervising the academic related activities made by teaching staff members. In First level management, staff members should interact with students to assess them in practical and theory knowledge by various assessment methods. 


\section{Functions of Board of Academic Council}

It should be dynamic one, frequently the board committee members able to identify the level of knowledge extraction from all candidates. If these corporate colleges were established in industries, the industry human resource department has to take decisions upon whether it is useful to improve, certified, assess the industry people's skill and for promoting their knowledge. Also, the council should define anyone approaches among the two; one is the student-centric approach, another one is the teacher-centric approach.

\begin{tabular}{|c|c|c|c|c|c|}
\hline \multicolumn{2}{|c|}{ Scool level education } & \multicolumn{2}{|c|}{ College level education } & \multicolumn{2}{|c|}{$\begin{array}{c}\text { Higher education to corporate } \\
\text { peoples }\end{array}$} \\
\hline Students: & Teacher: & Students: & Teacher: & Students: & Teacher: \\
\hline $\begin{array}{c}\text { Learner, } \\
\text { Follower, } \\
\text { Exam } \\
\text { Landidate, }\end{array}$ & $\begin{array}{c}\text { Knowledge } \\
\text { deliverer, } \\
\text { guide, mentor, } \\
\text { assessor, } \\
\text { Valuator }\end{array}$ & $\begin{array}{c}\text { Learner, } \\
\text { creator, self- } \\
\text { assessor, } \\
\text { valuable } \\
\text { candidate to } \\
\text { go to } \\
\text { corporate }\end{array}$ & $\begin{array}{c}\text { Guide. } \\
\text { Counselor, } \\
\text { facilitator, } \\
\text { Enriching the } \\
\text { skills to the } \\
\text { students }\end{array}$ & $\begin{array}{c}\text { Lommunicators, } \\
\text { knowledge } \\
\text { distributors }\end{array}$ & $\begin{array}{c}\text { Knowledge } \\
\text { absorber, } \\
\text { verifier, }\end{array}$ \\
assessor, \\
Valuator
\end{tabular}

Table.2 Teachers and Students contribution to various levels of Education

It is like sandwich courses or integrated courses with industrial collaboration. Whether professional can go to industry to assess the student's skills and knowledge? Industrial people should be satisfied with the motivation provided by academics professional through certification; they should promote the techniques such as offering awards, degrees. The Supervisor from academic institutions should be able to do monitoring the candidates who are doing higher studies in this organization. The council has to check whether any other organizations are available to motivate corporate people's knowledge and skills through awarding such degree. The council has to check if it is there any provision or industry policies to offer degree those who are doing higher studies from home environment can be availed within the industry HR level. Whether it is possible or not with academic support? From UG to PG can be found in this type in very least proportion, while PH.D take more admissions.

\section{Procedure for Student Admission Process}

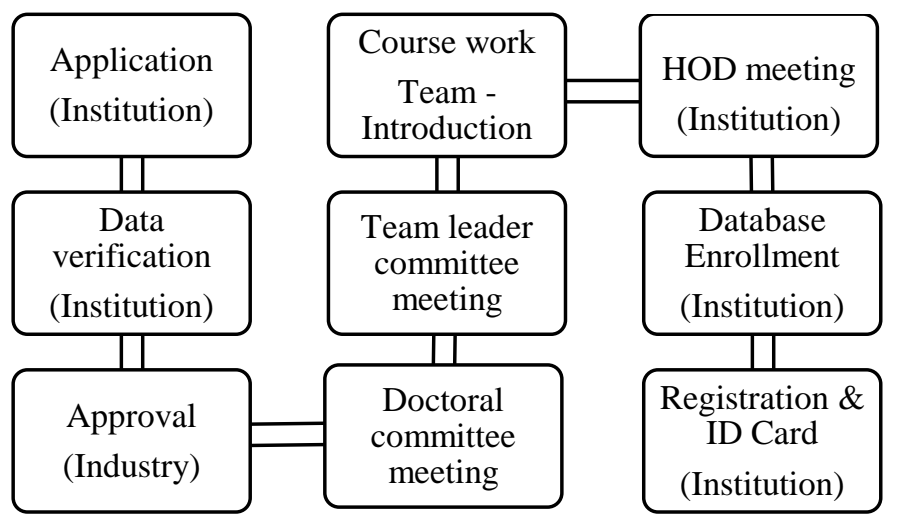

Fig.2.Admission Procedure \& scrutinizing process

An accreditation criterion needs to be satisfied for both Industry and Institution before taking any admission in any branch.Research Centre should be available in institutions so that everyone can share the ideas, issues related to all consumers. In India, some research and development companies, academic institutions have some research courses such as JRF, SRF. For admitting to these courses, students are elected through some competitive examinations. Here, Candidates from recognized industries may become eligible persons to seek admission in their own industry. The faculty members should be available from both industry and academicians. The standards and norms are available in the industry to start a course. Admission to various courses from basic 
courses to higher level courses will be offered based on their eligibility conditions and experiences. If a candidate with a basic course diploma, it is desirable to have some experiences in any one specialization or specialized area described in the curriculum. If it is UG level course, seeking admission to master degree course is eligible only based on experience gained in any particular specialized area. Likewise, admissions to Ph.D may be carried out using the same eligibility criteria. All the courses should have research accomplishments such as publications, innovations in any fields, completing all the subjects within the stipulated time period. The other motivation techniques include participation in lectures, seminars, industrial visits and conferences. These may also be considered as eligibility conditions in some higher level degree courses such as Master and doctoral level programs.

\section{Curriculum Design}

The curriculum should be designed as per the given requirements to provide adequate knowledge to the students. Frederico Matos (2013) this paper points that the changes being made at the Ph.D level degree appear to have had a negative impact on the depth of the doctoral research. Also in this paper, it is viewed that the following terms seem to have led the higher education or Ph.D to become a credential above anything else, the skills and training, the avoidance of topics deemed too original. So the assessment methods and curriculum design should follow the above-said terms in general. The three terms such as the timeline, the skill and training, the avoidance of topics deemed too original are to be implemented in this curriculum design of the proposed organization.

\begin{tabular}{|c|c|c|}
\hline $\begin{array}{c}\text { Industry - Human Resource } \\
\text { Department }\end{array}$ & $\begin{array}{c}\text { Academic - Human Resource } \\
\text { Department }\end{array}$ & $\begin{array}{l}\text { Knowledge Source from } \\
\text { Industry }\end{array}$ \\
\hline $\begin{array}{l}\text { Weekly digestive choice based } \\
\text { questions and it should be } \\
\text { related to work nature }\end{array}$ & $\begin{array}{l}\text { Weekly digestive choice based } \\
\text { questions and it should be related } \\
\text { to knowledge base }\end{array}$ & $\begin{array}{c}\text { Study of Work Nature \& } \\
\text { Presentation }\end{array}$ \\
\hline
\end{tabular}

Table.3. Curriculum Design Requirements

Overview of basic format for a course:

\begin{tabular}{|c|c|c|c|}
\hline Approach & Exam pattern & Assessment method & Duration \\
\hline $\begin{array}{l}\text { Learner-centered } \\
\text { paradigms }\end{array}$ & $\begin{array}{ll}\text { 1. } & \text { Online exam } \\
\text { 2. } & \text { Presentation } \\
\text { 3. } & \text { Interview }\end{array}$ & $\begin{array}{ll}\text { 1. Initial assessment } \\
\text { 2. Summative assessment } \\
\text { 3. } & \text { Formative assessment }\end{array}$ & $\begin{array}{l}\text { One month per } \\
\text { subject or six } \\
\text { months per semester } \\
\text { course }\end{array}$ \\
\hline
\end{tabular}

Table.4. Assessment formats and methods

\section{Assessment Procedure}

\begin{tabular}{|c|c|c|c|c|c|c|}
\hline Test / Exam & Subject & Weightage & $\begin{array}{c}\text { Duration of } \\
\text { Test / Exam }\end{array}$ & $\begin{array}{c}\text { Work with } \\
\text { presentation } \\
(50)\end{array}$ & $\begin{array}{c}\text { HR } \\
\text { Industry } \\
(25)\end{array}$ & $\begin{array}{c}\text { Total } \\
(100)\end{array}$ \\
\hline Monthly Test 1 & Paper 1 & $25 \%$ & $3 \mathrm{hrs}$ & $50 \%$ & $25 \%$ & 100 \\
\hline Monthly Test 2 & Paper 2 & $25 \%$ & $3 \mathrm{hrs}$ & $50 \%$ & $25 \%$ & 100 \\
\hline Monthly Test 3 & Paper 3 & $25 \%$ & $3 \mathrm{hrs}$ & $50 \%$ & $25 \%$ & 100 \\
\hline Monthly Test 4 & Paper 4 & $25 \%$ & $3 \mathrm{hrs}$ & $50 \%$ & $25 \%$ & 100 \\
\hline Monthly Test 5 & Paper 5 & $25 \%$ & $3 \mathrm{hrs}$ & $50 \%$ & $25 \%$ & 100 \\
\hline One semester & Papers & \multicolumn{5}{|c|}{ Grand total / One semester } \\
\hline
\end{tabular}

Table 5. Scoring method in assessing process

For each theory course, the assessment will be done on a continuous basis as follows: The Academic Council will decide from time to time the system of tests and examinations in each subject in each semester. For any particular course, the duration of course completion period may be 4 years, in this four year the total marks 1000 /per semester will be the maximum. The Grade is fixed based on their total marks obtained upon the completion of the course. Theory marks can be obtained through online one-word test conducted in the interval of monthly 5 exams. It is repeated for every semester and the total marks will be 1000 . The question paper should be like competitive exams question paper. The online exam is mostly prepared; course materials for 
every course with the tutorial videos should be available in the online. Industrial tour should be arranged by these institutions. "Learn to go" policy is used in academic institutions, as students are learning the basic things that should not be measurable, "Go to earn" policy should be used in corporate colleges, as people are doing work or something that could be measurable.

Y. Malini Reddy and Heidi Andrade, (2010) this paper shows that the usage of rubrics finds the gaps in the literature and proposes areas in need of research. Rubrics may also be an important part of this assessment procedure. Because, this paper says that the following terms could be improved by the usage of rubrics, student achievement, instruction and evaluating the program's outcome. The following Indirect assessment methods may be provided additionally, such as Surveys, Interviews, Giving lectures to students, Inviting students to industry, Presentation in front of faculties. Thinking level of the corporate peoples may be higher, so the value of their knowledge potentials can be easily assessed. This paper initiates the process in which the necessity of value based education and certification to industry people can be viewed and discussed. Student's qualifications and abilities to do education in this corporate college will be pointed out orally.

\section{Duties and Responsibilities:}

\begin{tabular}{|c|c|}
\hline Industry Faculties & Board of Administration \\
\hline $\begin{array}{l}\text { 1.Presentation verification } \\
\text { 2. Quality, reality, smart work identification } \\
\text { 3. HR questions, technical questions during } \\
\text { presentation } \\
\text { 4. Encouragements } \\
\text { 5. Assigning work } \\
\text { 6. Authority to provide TL position }\end{array}$ & $\begin{array}{l}\text { 1. Monitoring the quality of assessments, } \\
\text { infrastructures } \\
\text { 2. Faculty requirements, } \\
\text { 3. Coordinating peoples } \\
\text { 4. Elements of scientific } \\
\text { 5. management still used include: } \\
\text { 6. Using time and motion studies } \\
\text { 7. Hiring best qualified workers } \\
\text { 8. Designing incentive systems based on } \\
\text { output }\end{array}$ \\
\hline \multicolumn{2}{|c|}{ Board of Academic Council } \\
\hline \multicolumn{2}{|c|}{$\begin{array}{l}\text { 1. Monitoring the curriculum and syllabus } \\
\text { 2. Exam patterns } \\
\text { 3. Grading methods } \\
\text { 4. Revising and reviewing the assessments and work done by the candidate } \\
\text { 5. Review the organization's mission (the purpose of the organization). } \\
\text { 6. Evaluate available resources. } \\
\text { 7. Determine the goals individually or with input from others } \\
\text { 8. Write down the goals and communicate them to all who need to know. } \\
\text { 9. Review results and whether goals are being met. Make changes as needed. }\end{array}$} \\
\hline Students & Academic Faculties \\
\hline $\begin{array}{l}\text { Weekly Presentation, Work done previously, } \\
\text { Nature of work, Improvements if any, } \\
\text { Customer satisfaction, Effectiveness, Innovations } \\
\text { if any }\end{array}$ & $\begin{array}{l}\text { Verifying weekly assignments, } \\
\text { Presentations, Preparing questions monthly } \\
\text { test, Weekly lecture distribution. }\end{array}$ \\
\hline
\end{tabular}

Table.6.Overview of duties and responsibilities

\section{IV.Industries collaboration requirements: finding the eligibility and standards}

Research Center should be equipped with sufficient learning resources and materials so as the productivity of the industry would not be affected by the adoption of the learning environment. The faculties should have enough knowledge about the industry standards and their research center activities. An Industry should have laboratories, staff members, and online facilities with class rooms to get very high-level standards by the board of higher studies. Online courses and resources should be equipped in the research laboratory. The other network facilities should be used as a tool for assessing and monitoring the performance of the students. 
The knowledge potential that can be provided to students should be predetermined before starting the courses. People those who have well known to extract things from knowledgeable persons are eligible predominantly. Joanna Williams (2014), this paper reveals that higher education, as a public good, could improve national technological progress. So it depends upon the industry and its human capital. From that, it is observed that the importance of higher education must be involved with industrial experts. This paper says about the public good, social status and promotions of the people who are involving with the higher education which is encouraged by the government and private universities. Also, this paper refers to the knowledge which increases the job security and earnings to the graduates. The following three topics are discussed elaborately 'Public good and the pursuit of knowledge', 'Public good and human capital', 'Public good and the national economy'. Finally, it concludes that public good is perceived only to those who had higher education in their professional life. This article is an attempt to build an empirical ground for supporting the increased role of public funding in higher education. The rationale for the same becomes pertinent in the current scenario when 'public good' nature of higher education is rapidly eroding. So it is insisted forming such kind of rules in all the industries to support the higher education.

\section{PEAS description model: an Artificial intelligence approach to define the eligibility conditions and basic norms}

It is a wonderful tool to determine the functional activities of all the state holders in this organization. The high level communication between industry professionals and academic professionals will be considered as an effective process or a measure of effectiveness of this educational system. So this model will be considered as one of the effective tool to organize all the processes involving with the board of management and industrial academic council.

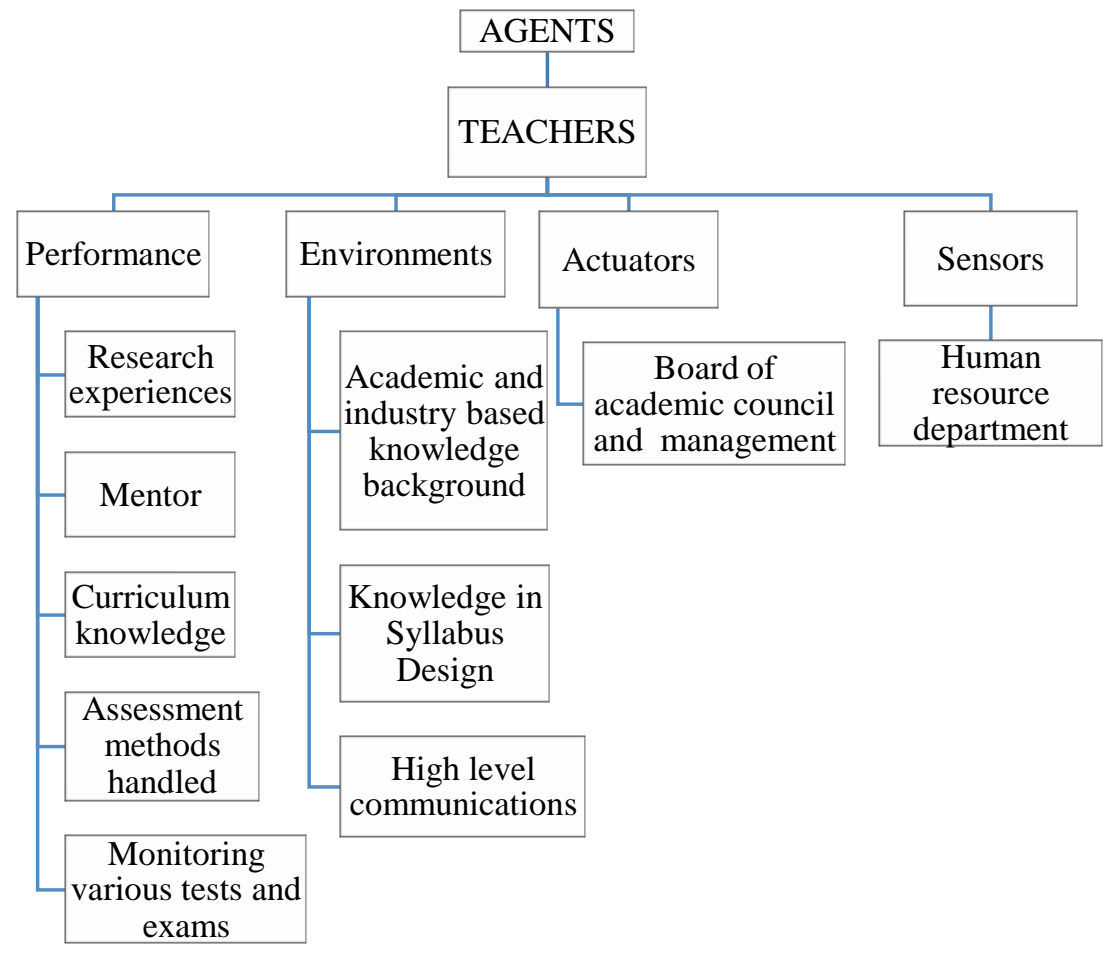

Fig.4.PEAS description model for a Teacher Recognition

Teachers and students are the most important peoples in the state holders group, so the PEAS model provided with only those members in this research. This tool and its functional output may be evaluated later with a survey conducted by the board of management. This survey will be used to improve the relationships with the management authorities to the other state holders. 


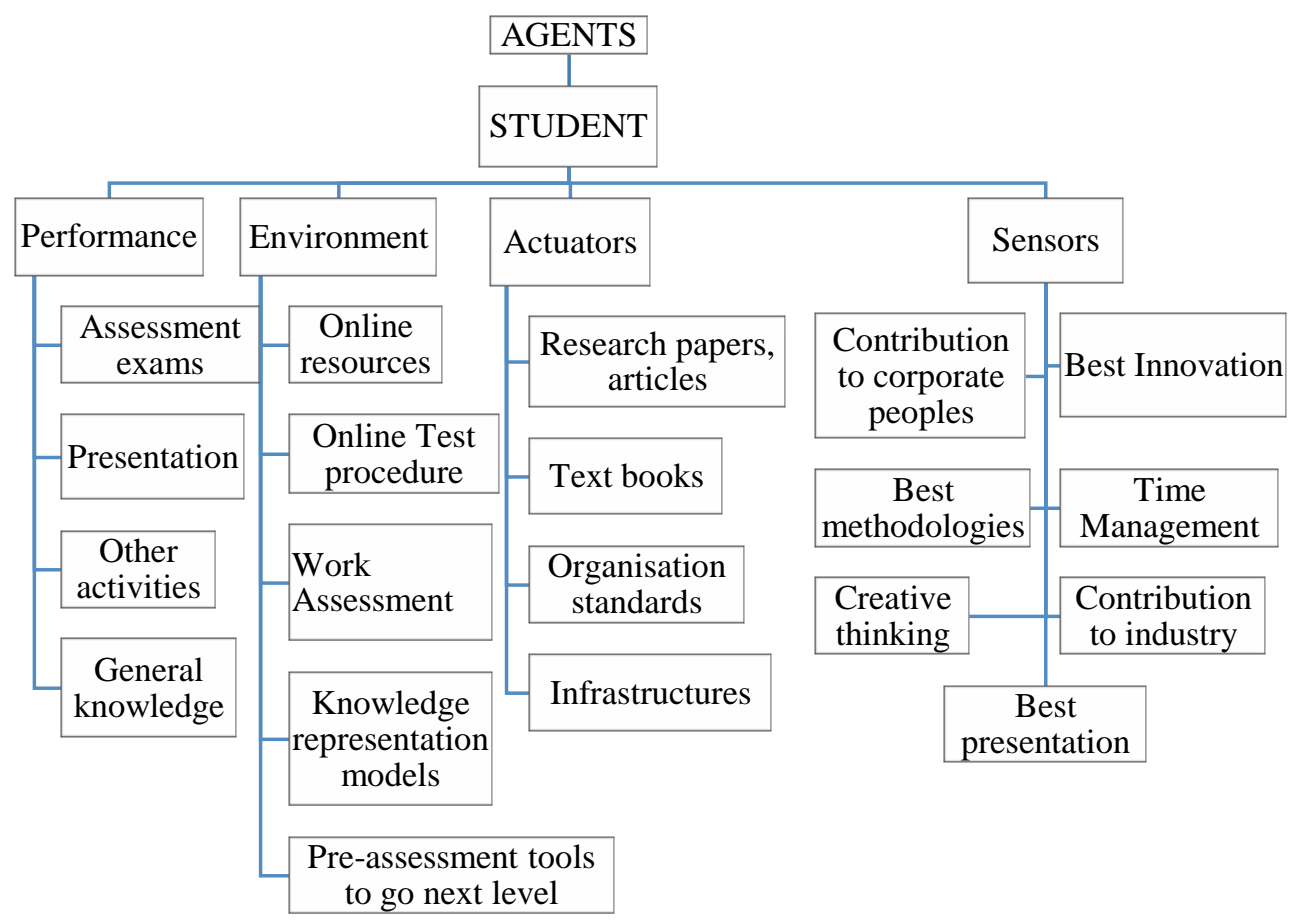

Fig.5.PEAS description model for a Student Recognition

\section{Contributions to the corporate world}

Research work can be done well by industry people than academic people in the perspective view of learners. The Ph.D and other curriculum and syllabus followed in these corporate institutions successfully completed in their home environment that means without the help of academic institutions. It could be observed that who is said to be the best learner among two Ph.D holders, one person from industrial and another one from academic? Really the practical knowledge gained by the industrial person is more; the practical knowledge input given to an industrial person is also more. The given courses are few examples for proving the above statement; design and analysis software trainings, product development courses such as CAD, CAM and automation courses such as PLC, SCADA. Industry people are gaining knowledge throughout the years; those things are not recognized by industry side and academic side also. Corporate people can accomplish their lifelong desires such as an interest in gaining more knowledge through learning. The Continuous learning process for individuals can be established in an effective manner in all industries to come out with their original abilities and skills. While taking promotion with a degree, this will become a very cheerful way of providing motivation. People can have a chance to get good recognition for their work and research. People would become more enthusiastic not only in learning management aspects but also in technological aspects. It becomes a very good tool to enlightening the team work across the various units in the same industry. Part time courses will be reduced in all colleges so as it will help both teachers and students to utilize their own time for learning and teaching. The communication gap between academics and industry can be decreased. The collaboration between academic research and customer's requirements will be more strengthened. More number of inventions may be recognized quickly as possible. A well-qualified education system can be formulated. Students directly can go to the industries to learn much more in industry scenario also.

\section{Overview of feasibilities for the implementation: requirements of a strong survey reports}

After completing a basic degree, it should be calculated how many years need to start next level degree. Industry people are gaining knowledge throughout the years. This is only for whether they need recognitions for that from industry side or from academic side. From industry side it is enough to start a new course without any experiences as they are exposed to more practical, but from academic side they need more basic theory. If these corporate colleges were established in industries, whether it is useful to improve, certified, assess the industry people skill, and promote their knowledge? Student centric approach may be initiated in industry based on only for promoting the knowledge transformation between professional people and academic peoples. The result obtained from the analysis showed that there existed relationship between employee motivation and the organizational performance.

MUOGBO U.S.(2013) the study reveals that extrinsic motivation given to workers in an organization has a significant influence on the workers performance. This is in line with equity theory which emphasizes that 
fairness in the remuneration package tends to produce higher performance from workers. The researcher recommends that all firms should adopt extrinsic rewards in their various firms to increase productivity.

\section{Conclusion}

Social status of corporate people will be saved, it is mainly meant in terms of certification. Collaboration work can be initiated for doing research between an academic institution and industry. It can be improved the academic status by means of providing the relationship between customer needs and currently available technologies. Entrepreneurship will be motivated by measuring their knowledge potentials based on their domain. The academic organization and Industry may be considered as a twin brothers of a great father, who is known as wisdom. Both are responsible to grasp the fruit of the wisdom. Where there is a combined effect of these two organization, there could be a successful human, renowned to the world as scientists, inventors, and engineers.

\section{References}

[1] David Boud\& Nancy Falchikov (2006) Aligning assessment withlong-term learning, Assessment \& Evaluation in Higher Education, 31:4, 399-413, DOI:10.1080/02602930600679050.

[2] Daniel Tan Lei Shek, Lu Yu, FlorenceKa Yu Wu \& Wen Yu Chai (2015) General University Requirements at Hong Kong Polytechnic University: evaluation findings based on student focus groups, Assessment \& Evaluation in Higher Education, 40:8, 1017-1031, DOI: 10.1080/02602938.2014.960362.

[3] Fengliang Li, Mengying Zhou \&Baolong Fan (2014) can distance education increase educational equality? Evidence from the expansion of Chinese higher education, Studies in Higher Education, 39:10, 1811-1822, DOI: $10.1080 / 03075079.2013 .806462$.

[4] Joanna Williams (2014): A critical exploration of changing definitions of public good in relation to higher education, Studies in Higher Education, DOI: 10.1080/03075079.2014.942270.KatrienStruyvena*, FilipDochya\& Steven Janssensa, (2010), Students' perceptions about evaluation andassessment in higher education: a review, Assessment \& Evaluation in HigherEducation, Volume 30, Issue 4, 2005.

[5] MUOGBO U.S. The Impact of Employee Motivation on Organisational Performance (A Study of Some Selected Firms in Anambra State Nigeria). The International Journal of Engineering and Science (IJES), Volume 2, Issue 7, Pages 70-80, 2013.

[6] Quratul - Ain Manzoor, Impact of Employees Motivation on Organizational Effectiveness, Department of Management Sciences, The Islamia University of Bahawalpur, Bahawalpur. European Journal of Business and Management ISSN 2222-1905 (Paper) ISSN 2222-2839 (Online) Vol 3, No.3

[7] Rafikul Islam Ahmad ZakiHj. Ismail, (2008),"Employee motivation: a Malaysian perspective", International Journal of Commerce and Management, Vol. 18 Iss 4 pp. $344-362$.

[8] Y. Malini Reddy \& Heidi Andrade (2010) A review of rubric use in higher education, Assessment \& Evaluation in Higher Education, 35:4, 435-448, DOI:10.1080/02602930902862859. 